\title{
Implementasi Metode Diskusi pada Pembelajaran Pendidikan Agama Islam
}

\author{
Nurhayati1, Sulaiman ${ }^{2}$ \\ nurhayatiyet97@gmail.com ${ }^{1}$, sulaiman@fis.unp.ac.id ${ }^{2}$ \\ Universitas Negeri Padang ${ }^{1,2}$
}

\begin{tabular}{|c|c|}
\hline$\overline{\text { ART }}$ & \multirow{10}{*}{$\begin{array}{l}\text { ABSTRACT } \\
\text { The background of this research is the low interest of } \\
\text { students in learning because the learning method is not of } \\
\text { interest to students. This study aims to find out (1) how the } \\
\text { implementation of the discussion method in PAI learning for } \\
\text { class XI MIPA students at SMA } 2 \text { Sijunjung, what are the } \\
\text { weaknesses and strengths of the discussion method, (3) what } \\
\text { are the supporting factors and inhibiting factors of the } \\
\text { discussion method. This type of research is qualitative } \\
\text { research with a descriptive method. This research was } \\
\text { conducted at SMAN } 2 \text { Sijunjung. The informants of this study } \\
\text { were the principal, curriculum representative, PAI teacher, } 3 \\
\text { students of class XI MIPA. Data collection techniques in this } \\
\text { study were by observing, interviewing, and recording the } \\
\text { ongoing interviews. The results of this study are about } \\
\text { implementing the discussion method in learning through the } \\
\text { classroom system so that students are excited and happy to } \\
\text { follow the process. }\end{array}$} \\
\hline$\overline{A r t i}$ & \\
\hline ebruari 2022 & \\
\hline Revi & \\
\hline Acce & \\
\hline Keyv & \\
\hline $\begin{array}{l}\text { Imple } \\
\text { Metod } \\
\text { Pendi } \\
\text { Islam }\end{array}$ & \\
\hline Conf & \\
\hline NOn & \\
\hline None & \\
\hline
\end{tabular}

Corresponding Author: Nurhayati, Department Islamic Education Faculty of Social Science Universitas Negeri Padang, Indonesia, Email: Nurhayatiyet97@gmail.com Phone No.: $+6282173056415$

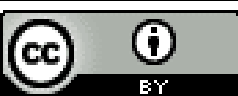 \\ Copyright $(2022$, Author(s)}

\section{Pendahuluan}

Pendidikan ialah suatu aktivitas yang dilakukan oleh pendidik dengan sengaja supaya peserta didik memiliki sikap serta kepribadian sangat baik, sehingga pendidikan diselengggarakan sesuai dengan Sistem Pendidikan (Mustaqim 2010). Muhaimin (2011) berkata bahwa keberhasil tidak tergantung pada pencapaian suatu tujuan satuan pendidikan bergantung pada bagaimana pencapaian suatu pendidikan yang dialami peserta didik mencakup aspek Kongnitif, Afektif serta Psikomotorik pada prestasi belajar. Agar terbentuknya perilaku dan kepribadian anak perlu adanya pembelajaran Pendidikan agama Islam, agar tercapainya tujuan pendidikan pada inginkan.

Tujuan Pendidikan Nasional berdasarkan UU No. 20 Tahun 2003, Pendidikan Nasional berfungsi menyebarkan kemampuan dan menghasilkan karakter serta peradaban bangsa menggunakan tujuan mencerdaskan kehidupan bangsa. agar berkembangnya kepribadian peserta didik menjadi manusia yang beriman dan 
Nurhayati dan Sulaiman: Implementasi Metode Diskusi Pada Pembelajaran Pendidikan...

bertakwa pada Allah, Berakhlak Mulia, Sehat, Berilmu, Cakap, Kreatif, serta menjadi rakyat Negara yang demokratis dan bertanggung jawab.

Sistem pembelajaran PAI bersifat menunjuk, mengasuh serta mengajarkan maupun melatih. Hal tersebut mengandung pengertian usaha menghipnotis jiwa melalui proses secara sedikit demi sedikit menuju suatu tujuan yaitu menanamkan ketaqwaan dan akhlak dan menegakkan kebenaran sebagai akibatnya terbentuklah insan berkepribadian dan budi pekerti luhur yang sesuai dengan ajaran Islam dengan ini adanya ketertarikan siswa untuk belajar.

Ketertarikan serta kesukaan belajar cenderung mampu didapatkan asal materi yang diajarkan sang guru dalam menyampaikan bahan ajar Jika bahan pelajaran dan cara guru menyampaikan pelajar tidak sinkron menggunakan ketertarikan siswa, maka peserta didik yang bersangkutan tidak bisa belajar menggunakan baik, karena tidak ada ketidak sukaan baginya. Begitu jua sebaliknya, Jika bahan pelajaran dan metode guru dapat menjadi daya tarik bagi siswa, maka hal itu akan mudah dimengerti dan mudah diterapkan dalam pikiran kognitif siswa, maka akan tercapainya suatu keberhasilan.

Selanjutnya untuk mencapai keberhasilan di dalam tak bisa dipisahkan dengan faktor psikologis peserta didik yaitu minat sebagaimana diungkapkan Slameto, (2013) Mengucapkan tentang minat sangat besar pengaruhnya tergantung kegiatan belajar peserta didik. Sehingga siswa mempunyai ketertarikan belajar yang tinggi maka akan menampilkan prestasi belajar yang baik. Dengan adanya minat belajar dalam diri siswa maka akan menampilkan keingintahuan dan kesukaan dalam diri siswa untuk terus belajar.

Kemuadian minat berperan besar didalam kegiatan belajar di sekolah, sebab minat akan berperan sebagai kekuatan untuk mendorong siswa untuk belajar. Peserta didik yang berminat maka sikapnya akan merasa sangat senang didalam pembelajaran, proses pembelajaran dan guru yang mengajarkannya, akan terlihat terdorong terus untuk tekun belajar. Berbeda dengan siswa yang sikapnya hanya suka menerima pelajaran, mereka hanya tergerak untuk ikut belajar tetapi sulit untuk bisa terus rajin karena tidak ada pendukungnya.

Menurut Syaiful, (2013) permasalah minimnya minat belajar siswa disebabkan cara guru mengajar lebih memilih metode ceramah maka menggunakan ini perlu memakai penerapan metode yang akan memberikan daya tarik, salah satunya yaitu metode diskusi. Metode diskusi yaitu perbimcangan ilmiah yang responsif mempunyai pertukaran pendapat yang dijalin menggunakan pertanyaan-pertanyaan problematis, pemunculan pandangan baru-pandangan baru serta pengujian ilham-ilham maupun pendapat yang disebsbkan oleh beberapa orang yang bergabung pada grup yang sehingga memperoleh pemecahan masalah serta mencari kebenaran.

Salah satu upaya untuk meningkatkan minat belajar merupakan menggunakan adanya metode yang mendukung untuk mencapai hal tersebut. berdasarkan Slameto, (2013:65), metode pedagogi yaitu salah satu jalan yang harus dilalui pada mengajar. Metode pengajaran pengajar yang tidak baik akan menghipnotis belajar peserta didik yang tidak baik juga serta keliru satu upaya untuk menciptakannya ialah dengan penggunaan metode pembelajaran. oleh sebab itu diperlukan metode pembelajaran yang Inovatif bisa membantu siswa agar lebih praktis memahami serta mencerna materi pelajaran secara aporisma. sehingga suatu tujuan sekolah tersebut terwujud 
Jika proses belajar mengajar pada selenggarakan secara efektif, merupakan dapat dilangsung secara lancar, terarah, serta sesuai dengan tujuan pembelajaran menggunakan adanya sekolah.

Salah satu metode yang bisa dipergunakan pada pembelajaran artinya metode diskusi bisa mengajak peserta didik, untuk bertukar pendapat sesama siswa untuk memecahkan dilema dalam pembelajaran. dari Armai Arief, (2002) Metode diskusi merupakan suatu penyajian atau penyampaian bahan pembelajaran pada mana guru memberikan kesempatan di para peserta didik atau gerombolan untuk mengadakan pembicaraan ilmiah guna mengumpulkan pendapat, membuat kesimpulan atau menyusun banyak sekali cara lain pemecahan persoalan. Jadi metode diskusi berguna untuk bertukar info, pendapat dan pengalaman yang telah dialami siswa. Penerapan metode diskusi pada pembelajaran artinya supaya kegiatan belajar mengajar bisa menjadi lebih efektif serta alternatif yang sangat baik bagi pengajar untuk digunakan pada proses penyampaian gosip pada pembelajaran PAI, sebagai akibatnya peserta didik menjadi bersemangat mengikuti proses pembelajaran.

Dengan demikian untuk mencapai hal tersebut diharapkan seseorang guru bisa membangun serta mengupayakan perubahan tingkah sikap siswa keseluruhan menjadi akibat pengalaman pada hubungan. Selanjutnya seseorang guru dituntut juga untuk memiliki kepekaan pada melihat minat belajar siswa, sehingga mengetahui perseteruan belajar yang dihadapi peserta didik. Disamping itu, pengajar wajib terampil menerapkan metode-metode mengajar yang baru sebagai akibatnya dapat menaikkan minat siswa untuk belajar serta dapat mempertinggi hasil belajar siswa. pada pemilihan metode mengajar haruslah dipertimbangkan secara sempurna, efisien, serta efektif.

\section{Tinjauan Pustaka}

Ruang lingkup ketentuan pendidikan Islam meliputi pendidik (subyek) dan perbuatan mendidik, anak didik (obyek), metode pendidikan serta alat-alat pendidikan dan lingkungan pendidikan berdasarkan pendekatannya, pendidikan terbagi menjadi dua yaitu, pendidikan berdasarkan pendekatan ilmiah dan pendidikan berdasarkan pendekatan sistem. PAI merupakan suatu pendekatan ilmiah seperti pendekatan disipliner dan pendekatan fungsioner tergantung pada permasahan Islam serta pendidikan Islam berdasarkan pendekatan sistem merupakan pendidikan yang lebih mendekati pola berpikir yang empiris dan intuitif.

Salah satu metode yang bisa digunakan dalam pembelajaran adalah metode diskusi dapat mengajak siswa, untuk bertukar pendapat sesama siswa untuk memecahkan masalah dalam pembelajaran. Menurut Armai Arief, (2002) Metode diskusi merupakan suatu cara penyajian atau penyampaian bahan pembelajaran di mana guru memberikan kesempatan pada para siswa atau kelompok untuk mengadakan pembicaraan ilmiah guna mengumpulkan pendapat, membuat kesimpulan atau menyusun berbagai alternatif pemecahan masalah. Jadi metode diskusi berguna untuk bertukar informasi, pendapat dan pengalaman yang sudah dialami siswa. Penerapan metode diskusi dalam pembelajaran merupakan salah satu solusi agar kegiatan belajar mengajar bisa menjadi lebih efektif dan alternatif yang sangat baik bagi guru untuk digunakan dalam proses penyampaian informasi dalam pembelajaran PAI, sehingga siswa menjadi bersemangat mengikuti proses pembelajaran. 
Nurhayati dan Sulaiman: Implementasi Metode Diskusi Pada Pembelajaran Pendidikan...

Dengan demikian untuk mencapai hal tersebut dibutuhkan seseorang guru yang bisa menciptakan dan mengupayakan perubahan tingkah laku siswa secara keseluruhan sebagai hasil pengalaman dalam interaksi. Selanjutnya seorang guru dituntut juga untuk memiliki kepekaan dalam melihat minat belajar siswa, sehingga mengetahui permasalahan belajar yang dihadapi siswa. Disamping itu, guru harus terampil menerapkan metode-metode mengajar yang baru sehingga dapat meningkatkan minat siswa untuk belajar serta dapat meningkatkan hasil belajar siswa. Dalam pemilihan metode mengajar haruslah dipertimbangkan secara tepat, efisien, dan efektif. Serta metode yang digunakan hendaknya memberikan ruang bagi siswa dalam berinteraksi dengan sesama siswa.

Metode diskusi adalah salah satu cara mendidik yang berupaya memecahkan masalah yang dihadapi, baik dua orang atau lebih yang masingmasing mengajukan argumentasi atau pendapat memperkuat pendapatnya (Pupuh, 2010:62) sehingga meningkatlah minat belajar siswa. Minat sangat pengaruh besar terhadap belajar, karena apabila bahan pelajaran yang digunakan tidak sesuai dengan minat siswa, maka siswa tidak akan belajar dengan sebaik-baiknya, karena tidak ada ketertarikan bagi dirinya. Sehingga malu untuk belajar, ia tidak memperoleh kepuasan dari pelajaran tersebut (Slameto ,2013). Implementasi atau penggunaan metode diskusi merupakan suatu cara untuk melancarkan suatu pembelajaran sehingga siswa dapat mengikuti pembelajaran dengan baik sesuai dengan langkah langkah penerapan metode. Berdasarkan uraian diatas disimpulkan mengenai tinjauan pustaka dari implementasi metode diskusi dalam meningkatkan minat belajar yaitu melaksanaan segala kegiatan yang terencana untuk memperoleh hasil yang efektif dan efisien sesuai dengan tujuan yang ditentukan sehingga meningkatnya minat belajar siswa.

Dalam kamus besar bahasa Indonesia, implementasi mengandung arti pelaksanaan atau penerapan. Artinya yaitu yang dilakukan dan diterapkan adalah kurikulum yang telah dirancang atau didesain yang kemudian dijalankan sepenuhnya. Implementasi disamping dipandang sebagai sebuah proses, implementasi juga dipandang sebagai penerapan sebuah inovasi dan senantiasa melahirkan adanya perubahan kearah inovasi atau perbaikan, implementasi dapat berlangsung terus menerus sepanjang waktu. Nana Syaodih sebagaimana dikutip oleh Syaifuddin (2006) mengemukakan bahwa proses implementasi setidaknya ada tiga tahapan atau langkah yang harus dilaksanakan, yaitu: tahap perencanaan, pelaksanaan, dan evaluasi.

\section{Metode}

Jenis penelitian yang dipergunakan ialah field research atau penelitian kualitatif dengan menggunakan metode deskriptif (Sugiyono, 2012). Menurut Herdiansyah (2014:9) penelitian kualitatif bertujuan untuk mengartikan sebuah fenomena yang terjadi secara berita dan kenyataan pada lokasi penelitian, menjumpai masalah secara menyeluruh serta konteks sosial secara ilmiah dengan mengutamakan proses korelasi komunikasi yang intensif antara peneliti menggunakan keadaan yang terjadi dilapangan. Penelitian ini bermaksud menyampaikan gambaran menggunakan implementasi penggunaan metode diskusi pada menaikkan pada pembelajaran Pendidikan agama Islam siswa kelas XI di SMAN 2 Negeri Sijunjung.

Metode penelitian yang digunakan dalam penelitian ini adalah menggunakan model atau metode penelitian kualitatif Penelitian ini dilakukan dari bulan Desember 2021Februari 2022. Tempat penelitiannya di SMAN 2 Sijunjung. Informan penelitian ini 
adalah kepala sekolah, wakil kurikulum, guru PAI, dan perwakilan siswa kelas XI MIPA yang berjumlah 3 orang siswa.

Instrumen penelitian kualitatif melalui manusia membuat pedoman observasi, pedoman wawancara, dan lain sebagainya. dapat pula digunakan hanya sebatas pendukung dari tugas peneliti, sebagai instrumen kunci (Alhamid \& Anufia, 2019: 2). Adapun yang menjadi informan dalam penelitian diantaranya: a) kepala sekolah. b) wakil kurikulum, c) guru PAI. d) siswa kelas XI MIPA. Dalam skripsi ini penulis atau peneliti akan menggunakan instrumen penelitian pendukung yaitu alat rekam.

Teknik pengumpulan data dalam penelitian ini yaitu dengan melakukan observasi serta pengamatan melakukan wawancara, dan merekam wawancara berlangsung. Teknik analisis data dilakukan peneliti yakni teknik analisis data kualitatif. Menurut Miles dan Huberman didalam buku Sugiyono (2012: 247-252) Tahap-tahap analisis data sebagai berikut yakni mereduksi data, penyajian data, dan pembuktian data. Teknik pengabsahan data pada penelitian iniada yaitu teknik analisis data dan triangulasi sumber.

\section{Hasil dan Pembahasan}

\section{Implementasi metode diskusi pada pembelajaran PAI kelas Xxi MIPA di SMAN 2 Sijunjung}

Dalam sebauah implementasi metode diskusi pasti akan menemuka cara mengimlemtasikan, kelebihan dan kekurangan dan faktor pendukung dalam berdiskusi.

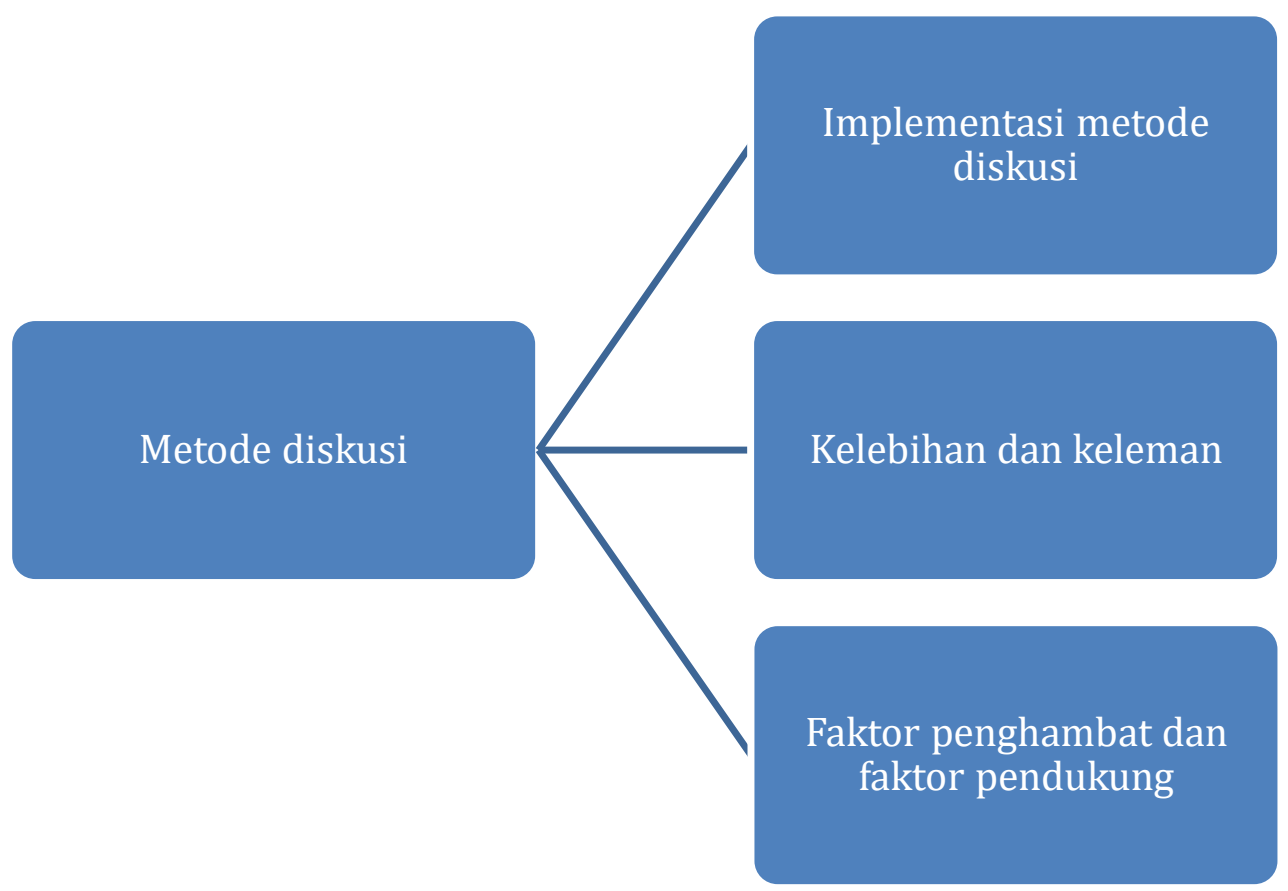

Bagian-bagian dalam pengimplemetasikan metode diskusi dalam meningkatkan minat belajar.

1. Implementasi metode diskusi

implementasi metode diskusi merupakan suatu cara untuk melancarkan suatu pembelajaran sehingga siswa dapat mengikuti pembelajaran dengan baik sesuai dengan langkah langkah penerapan metode. 
Nurhayati dan Sulaiman: Implementasi Metode Diskusi Pada Pembelajaran Pendidikan...

2. Kelemahan dan kelebihan

Kelemahan dan kelebihan merupakan sustu yang akan terjadi pada saat penngimplentasi kan metode diskusi berlangsung yaitu berjalan lancer atau tidak.

3. Faktor pendukung dan faktor penghambat

Pada bagian ini merupakan suatu tantangan guru melakukan metode diskusi tersebut karna tergantung pada kondisi siswa dalam pembelajaran.

Dalam mengimplementasikan metode diskusi dalam meningkatkan minat belajar pada pembelajaran pendidikan agama Islam (PAI) di sekolah, SMA Negeri 2 Sijunjung mempunyai perencanaan dan pelaksanaan dalam menggunakan metode diskusi dalam pembelajaran sebagai berikut:

Perencanaan dilakukan yang pertama yaitu dari pendidik. Pendidik mempunyai peran penting dalam melaksanakan metode diskusi dalam pembelajaran. Perencanaan perlu dilakukan untuk menentukan keberhasilan proses suatu pembelajaran yang akan dilaksanakan, berhasil atau tidaknya suautu pembelajaran dapat dilihat bagaimana seorang pendidik merencanakannya, begitu juga dengan penggunaan metode diskusi, jika tidak direncanakan dengan baik maka penggunaan metode diskusi tidak berjalan dengan baik. Sebelum memulai pembelajaran apa yang harus dilakukan guru melaksanakan kegiatan belajar mengajarnya (KBM) diungkapakan oleh Dra Harnetti, M.Si (5 Januari 2022) selaku kepala sekolah sebagai berikut:

"Sebelum memilai kegiatan belajar mengajar guru harus mempersiapkan diri untuk memulai proses kegiatan belajarnya dan guru juga menyiapakan atau merencanakan keperluan apa saja yang digunakan dalam pembelajaran"

Kemudian Ibu Mona Amelia, S. Pd (4 Januari 2022 pada) selaku Waka Kurikulum SMA Negeri 2 Sijunjung mengatakan bahwa:

"Perencanaan pada pembelajaran yaitu kerjasama yang tidak hanya menitik beratkan suatu kegiatan guru atau kegiatan peserta didik saja tetapi juga guru dan peserta didik bekerjasama secara bersama-sama berusaha mencapai tujuan pembelajaran yang telah ditentukan".

Sebelum pendidik melakukan pembelajaran hendaknya pendidik terlebih dahulu mepersiapakan sesuatu yang akan dilakukan ketika akan menggunakan metode diskusi. Sebelum menggunakan metode diskusi, guru PAI SMA N 2 Sijunjung menetapkan bentuk metode diskusi seperti apa yang akan digunakanmenetapkan bentuk metode diskusi seperti apa yang akan digunakan, menentukan materi apa yang akan dipelajari saat itu, sedikit pemberian motivasi dan gambaran mengenai yang akan dipelajari saat itu. Sehingga siswa tidak bingung dan antusias dalam mengikuti pelajaran dan mengerjakan semua tugas yang akan diberikan oleh guru kepada mereka. Seperti yang disampaikan oleh Ibu Nur Efriyanti, S. Pd I (4 Januari 2022) selaku guru PAI mengatakan:

"Sebelum memulai melakukan metode diskusi saya memberikan kepada siswa terlebih dahulu saya menentukan penerapan diskusi apa yang akan digunakan dengan menjelaskan peraturan-peraturan selama proses pelaksanaan diskusi berlangsung. Sehingga dalam penyampai bisa dilakukan secara maksimal sehingga siswa tidak akan bingung terkait apa yang akan dilakukan ketika diskusi sedang berlangsung, sehingga anak-anak dapat dengan mudah mengerjakan tugas yang telah saya diberikan kepada mereka dan dapat memecahkan masalah yang sedang dibahas sehingga tujuan pembelajaran dapat dicapai dengan baik". 
Berdasarkan beberapa data di atas, dengan menggunakan metode diskusi siswa tidak mendengarkan banyak ceramah dari guru. Pembelajaran ini tidak hanya terpusat pada guru karana guru hanya sedikit memberikan penjelasan di awal mengenai materi dan mengarahan mengenai pelaksanaan pembelajaran yang akan dilaksanakan nantinya. Materi yang diberikan tidak banyak dikarena akan dibagi menjadi beberapa kelompok dan dikerjakan atau dimusyawarahkan secara bersama-sama. Sehingga siswa tidak mengalami kesulitan dalam mengerjakan dan tujuan kegiatan belajar tercapai.

Pelaksanaan penggunaan metode diskusi dalam pembelajaran pendidikan agama Islam di SMA Negeri 2 Sijunjung sudah cukup berjalan cukup baik dan mempunyai kemajuan yang sangat baik. Adapun pelaksanaan penggunaan metode diskusi dalam pembelajaran pendidikan agama Islam di SMA Negeri 2 Sijunjung, Menurut Dra Harnetti, M. Si (5 Januari 2022) selaku kepala sekolah di SMAN 2 Sijunjung mengatakan:

"Langkah awal pelaksanaan metode diskusi yaitu kepada tekanan ketepatan, selanjutnya pada kecepatan dan akhirnya siswa dapat memahami materi pembelajaran PAI dengan cepat. Metode diskusi ini harus sering dilakukan, karena dengan ini siswa akan memperoleh materi yang sangat banyak sehingga melekat dan tidak membosankan. Pelaksanaan metode diskusi harus sangat semenarik mungkin, serta di selingi dengan berbagai variasi. Kemudian menambah dan menumbuhkan semangat belajar anak didik. Yang terpenting diskusi harus disesuaikan dengan kemampuan dan kondisi anak didik nya."

Selanjutnya menurut Ibu Mona Amelia, S. Pd (4 Januari 2022) selaku Waka Kurikulum SMA Negeri 2 Sijunjung mengatakan bahwa:

"Dalam proses pelaksanaan penggunaan metode diskusi di sekolah dapat meningkatkan ke aktifan siswa dalam menyampaikan materi, menjawab pertanyaan, dan menyelesaikan masalah dalam diskusi serta menyimpulkan hasil diskusi".

Sedangkan menurut Ibu Nur Efriyanti S. Pd. I (4 Januari 2022) selaku guru PAI mengatakan:

"Pelaksanaan metode diskusi pada pembelajaran PAI haruslah diatur terlebih dahulu dengan adanya beberapa aturan saat diskusi berlangsung atau dalam istilah lain adanya manajemen dari guru yang akan mengajar dan yang akan menggunakan metode diskusi sebagai metode pembelajarannya. Itu dimaksudkan agar para siswa nantinya merasa nyaman dan enjoy saat mengikuti pembelajaran, sehingga dapat meningkatkan pemahaman siswa mengenai materi yang sedang disampaikan."

Beberapa hal tersebut diperkuat dengan hasil yang peneliti lakukan. Saat peneliti dapat menyimpulkan bahwa proses pembelajaran dengan metode diskusi yang dilakukan oleh guru PAI membuat nyaman siswa, serta mendapatkan perhatian lebih dari siswa, siswa terlihat sangat senang dan menikmati setiap proses pembelajarannya, dan hampir semua siswa konsentrasi pada materi PAI yang sedang disampaikan oleh guru PAI.

Hal itu diperkuat pula dari hasil wawancara peneliti dengan saudari Melati selaku siswa kelas XI MIPA 1 mengenai metode diskusi, yaitu:

"Iya bu, ibu guru sering dalam menggunakan metode diskusi seperti ini. Dan saya merasa sangat senang dengan metode diskusi ini. Karena saya cepat memahami materi yang 
Nurhayati dan Sulaiman: Implementasi Metode Diskusi Pada Pembelajaran Pendidikan...

disampaikan dan apa bila diberikan tugas akan cepat selesai dengan mengerjakan tugas secara berdiskusi."

Sama dengan yang diutarakan oleh siswa kelas XI MIPA 2 dan 3, Saudara Genta yaitu: "Saya sangat senang jika saat diajar dengan diskusi seperti ini. Enaknya lebih cepat paham dan jika ada tugas bisa dikerjakan dengan musyawarah bareng teman-teman satu kelompok, sehingga lebih cepat terselesaikan bu."

Dalam hal ini peneliti dapat menyimpulkan bahwa penggunaan metode diskusi di SMP Negeri 1 Sijunjung yaitu melalui penggunaan metode diskusi ini keaktifan dan minat siswa dalam menyampaikan materi, menjawab pertanyaan, menyelesaikan masalah dan dapat menyimpulakan hasil diskusi. Sehingga siswa merasa senang apabila diberikan tugas mereka cepat menyelesaikanya.

Pelaksanaan penggunaan metode diskusi dalam pembelajaran pendidikan agama Islam di SMA Negeri 2 Sijunjung sudah cukup berjalan cukup baik dan mempunyai kemajuan yang sangat baik. Adapun akhir dari pelaksanaan penggunaan metode diskusi dalam pembelajaran pendidikan agama Islam di SMA Negeri 2 Sijunjung, Menurut Dra Harnetti, M. Si (5 Januari 2022) selaku kepala sekolah di SMAN 2 Sijunjung mengatakan:

"Setelah selesai melakukan pembelajaran dengan menggunakan metode diskusi siswa dapat mengerjakan tugas dengan baik dan lancer karena mereka sudah sangat memahami yang telah diberikan sehingga tugas yang di buatnya akan di selesaikan dengan mudah."

Selanjutnya menurut Ibu Mona Amelia, S. Pd (4 Januari 2022) selaku Waka Kurikulum SMA Negeri 2 Sijunjung mengatakan bahwa:

"Akhir dari metode diskusi ini yaitu siswa akan lebih bersemangat lagi dalam mengerjakan tugas karna mereka merasa suka terhadap apa yang telah di berikan gurunya sehingga tugas yang diberikan guru dapat terselesaikan dengan lancer. Dengan melakukan metode diskusi ini siswa akan lebih aktif dan memberikan pendapat."

Sedangkan menurut Ibu Nur Efriyanti, S. Pd. I (4 Januari 2022) selaku guru PAI mengatakan:

"Saya merasa sangat senang melihat anak anak dapat mengerjakan tugas dengan baik karna menggunakan metode diskusi ini siswa mempunyai wawasan yang luas serta bertukar fikiran sehingga apabila ada suatu permasalahan maka akan terselesaikan dengan mudah".

Hal itu diperkuat pula dari hasil wawancara peneliti dengan saudari Melati selaku siswa kelas XI MIPA 1 mengenai metode diskusi, yaitu:

"Saya sangat bersemangat mengikuti diskusi ini karna ini dapat menantang danya bertukar pendapat untuk menyelesaikan suatu masalah dan tugas yang diberikan dapat dikerjakan dengan mudah karna sudah dipahami dengan baik".

Dari pendapat di atas dapat disimpulkan bahwa akhir dari pembelajaran tersebut adalah siswa sangat bersemngat mengikuti prose pembelajran menggunakan metode diskusi karna mereka dapat bertukar fikiran sehingga apablia mereka diberikan tugas akan dapat diseselaikan dengan cepat. 


\section{Keunggulan dan Kelemahan Metode Diskusi Pada Pembelajaran Pendidikan Agama Islam Siswa Kelas XI MIPA di SMA Negeri 2 Sijunjung.}

Dalam sebuah proses pembelajaran tentu memiliki kelebihan dan kelemahan metode diskusi. Kelebihan dalam melaksanakan metode diskusi yaitu dapat membuat siswa lebih aktif dan lebih kritis dalam menyampaikan maupun dalam menyelesaikan masalah. Keunggulan metode diskusi di antaranya meransang siswa menjadi kretif dapat memberikan gagasan yang luas, lebih berani mengungkapkan pendapat, suasana kelas menjadi hidup yaitu saling bertukar pikiran, menghargai pendapat orang lain, dapat memecahkan masalah, bertanggung jawab dan bekerja sama.

Kelemahan merupakan suatu yang tidak diinginkan di luar dugaan, berikut kelemahan metode diskusi yang terjadi di antaranya pembicaraan terkadang menyimpang, sehingga memerlukan waktu yang Panjang, tidak bisa dipakai pada kelompok yang besar, peserta mendapat informasi yang terbatas, dan kemungkinan besar diskusi hanya yang pandai berbicara.

Kelemahan yang dipaparkan yaitu banyaknya penyitaan waktu sehingga siswa menjadi bosan dan adanya perdebatan tida hentinya sehingg suasana kelas menjadi tidak kondusif. Maka dengan ini suapya tidak terjadi guru harus mempersiapkan diri suapaya tidak terjadi hal ini, agar tidak terjadi guru akan mengambil alih diskusi yang sedang berlanggsung.

Dalam melaksanakan pembelajaran tentunya selalu kita temukan hambatan. Hambatan biasanya diartikan sebagai sekumpulan masalah ataupun kendala yang memperlambat majunya suatu tujuan yang akan dicapai dan harus segera ditangani. Jika dikaitkan dengan implementasi penggunaan metode diskusi pada pembelajaran PAI, maka hambatan yang dirasakan guru adalah kurangnya keseriusan siswa dalam proses diskusi sedang berlangsung. Hal ini sesuai dengan Ibu Dra Harnetti, M. Si (5 Januari 2022) selaku kepala sekolah di SMAN 2 Sijunjung mengatakan:

"Faktor penghambat terdapat pada karakter siswa sendiri, kadang ada rajin, malas, atau malu untuk maju kedepan kelas, bagaimana kita membantunya. Kemudian dizaman sekarang media sosil sangat mempengaruhi anak-anak, sehingga waktu mereka untuk mau belajar dan berinteraksi dengan temannya mengajak ke arah media social sehingga akhirnya, siswa menjadi korbankan dengan rasa ingin tahunya, kalau orang tuanya tidak mendukung dalam proses belajar, saya rasa itu akan menjadi hambatan terbesar, faktor kedua adalah faktor dorongan orang tua yang harus benar-benar suport (mendukung) pembelajaran di rumah.

Menurut Ibu Mona Amelia, S. Pd (4 Januari 2022) selaku Waka Kurikulum SMA Negeri 2 Sijunjung mengatakan bahwa:

"Kendalanya menurut saya latar belakang anak yang berbeda-beda. Mengapa saya katakan demikian? karena seperti kita ketahui tidak semua anak mempunyai kemampuan yang sama dalam merespon dalam belajar maka dengan itu kita kenali siswa tersebut sehingga dia minat mengikuti proses belajar dengan baik, maka dengan ini timbulnya minat siswa sehingga proses penggunaan metode pembelajaran bisa diikutinya dengan baik dan kurang sarana prasarana yang digunakan guru ndalam pembelajaran".

Faktor penghambat pertama yang dikemukakan oleh kepala sekoalah adalah karakter dari para siswa sendiri. Hal tersebut berarti lebih kepada penguasaan guru 
Nurhayati dan Sulaiman: Implementasi Metode Diskusi Pada Pembelajaran Pendidikan...

dalam kelas. Menurut Ibu Dra Harnetti, M. Si, media sosial yang berkembang saat ini begitu mempengaruhi semangat belajar dari para siswa. Perhatian para siswa saat ini lebih terfokus pada sosial media, sehingga waktu yang seharusnya digunakan untuk belajar menjadi berkurang. Kemudian, hal ini berpengaruh pula pada proses pembelajaran didalam kelas, sehingga para siswa tidak siap dalam menerima materi yang akan diajarkan oleh guru pada saat itu.

Faktor penghambat selanjutnya adalah kurangnya dukungan orang tua dalam memberikan dorongan agar anaknya semangat belajar di rumah. Ketika anak tersebut mulai tidak bersemangat untuk belajar dirumah, maka kemudian anak tersebut juga tidak begitu mempersiapkan diri atau memiliki semangat untuk belajar di sekolah dan selanjutnya kurangnya sarana prasarana digunakan oleh guru dalam melakukan penggunaan metode diskusi dalam kelas sehingga siswa kurang mengikuti.

Berdasarkan pada faktor-faktor penghambat pelaksanaan diskusi yang dituturkan oleh Harnetti dan Mona lebih kepada faktor-faktor eksternal penghambat belajar siswa secara umum. Hal ini terlihat dari Harnetti dan Mona yang lebih mengarah pada faktorfaktor penghambat siswa dalam belajar yang berasal dari luar kelas dan berpengaruh hingga kedalam kelas. Kemudian, dari penjelasan Harnetti dan Mona juga dapat diketahui bahwa apapun metode yang digunakan faktor-faktor penghambat yang telah disampaikan tersebut dapat menjadi penghambat dalam menerapkan metode didalam kelas baik itu metode ceramah, metode tanya jawab, bahkan metode diskusi.

Faktor pendukung adalah sesuatu yang membantu, mendukung dalam suatu hal. Dalam pelaksanan penggunaan metode diskusi ada beberapa hal yang menjadi faktor pendukung implementasi metode diskusi dalam meningkatkan minat belajar siswa pada pembelajaran pendidikan agama Islam di SMA Negeri 2 Sijunjung, data yang ditemukan oleh peneliti dari hasil wawancara dengan Ibu Dra HARNETTI, M. Si (5 Januari 2022) selaku kepala sekolah di SMAN 2 Sijunjung mengatakan:

"Hal pertama yang harus kita lakukan adalah merangsang minat mereka dulu, minat mereka mau belajar, mau memahami apa yang kita ajarkan. Caranya yang utama adalah memberikan suatu pertanyaan, walaupun terkadang pertanyaan itu diluar dari bab yang kita ajarkan, berikan mereka itu nalar sekolah, kita bikin hadiah, baru setelah itu kita kasi berikan mereka berani maju ke depan, supaya tidak mengantuk, ada yang tidak mengerti itu kan berikan kepercayaan ke mereka berinteraksi di depan. Misalnya kalau berbicara tentang bab iman kepada Allah, iman kepada kitab Allah ada taurat, zabur, injil, kita untuk selang-seling berdasarkan tempat duduk aja itu di depan papan tulis, tiga orang maju, kalau kita langsung sodorkan kitab ini diturunkan untuk Rasul ini, kan kalau $k$ seperti itu monoton berarti, berikan interaksi anak-anak untuk maju ke depan mungkin polanya misalnya dengan cara game atau diskusi. selang-seling berdasarkan tempat dudukurutannya nanti yang pertama siapa, kalau tidak berani nanti kita ambil dua lah itu cara yang kedua".

Hal pertama yang menjadi faktor pendukung dalam pelaksanaan metode diskusi yakni minat belajar dari para siswa. Minat belajar sangat berpengaruh pada proses belajar dan mengajar, karena dengan adanya minat dalam mempelajari suatu materi para siswa menjadi lebih semangat dalam belajar dan lebih mudah untuk memahami materi yang diajarkan. 
Menurut Ibu Mona Amelia, S. Pd (4 Januari 2022) selaku wakil kurikulum juga menyampaikan hal lain yang menjadi faktor pendukung dalam pelaksanaan metode diskusi, yakni:

"Sarana dan prasarana dipastikan menjadi faktor pendukung utama dalam pembelajran karena tanpa adanya maka prosese belajar tidak akan menjadi baik selanjurtnya faktor pendukung lainya yaitu adanya buku paket, alat peraga, untuk memudahkan siswa untuk belajar, kalau tida ada buku paketnya bagaimana mau belajar karna buku tersebut adalah panduan dalam belajar karna materi yang akan di pelajari sudah ada disana harus belajar. Kemudian faktor pendukung lainnya yaitu aturan dalam berdiskusi, supaya mereka tidak asik sendiri."

Selanjutnya menurut Ibu Nur Efriyanti, S.Pd. I (4 Januari 2022) selaku guru PAI mengatakan:

"Kalau dipahami keberadaan PAI itu sangat berperan besar bagi peserta didik di sekolah, pengalaman saya mengajarkan mata pelajaran PAI di kelas itu menyenangkan. Ketika proses kegiatan belajar mengajar (KBM) mata pelajaran PAI berlangsung, hal yang mendukung terinternalisasinya yaitu ketika menggunakan metode diiskusi ini didukung oleh sarana dan prasarana kelas yang baik dan bagus maka minat belajar peserta didik, suasana kelas, kebersihan kelas dan lain- lainya, apabila semuanya terpenuhi maka proses pembelajaran PAI akan lancar sehingga nantinya implementasi pengunaan metode diskusi akan berjalan dengan baik"

Maka dari hasil wawancara di atas yang menjadi faktor pendukung implementasi penggunaan metode diskusi dalam meningkatkan minat belajarb siswa pada mata pembelajaran pendidikan agama Islam di SMA Negeri 2 Sijunjung adalah minat belajar siswa dan sarana prasarana dikelas, suasana kelas, kegiatan pengembangan peserta didik di luar KBM, perhatian guru terhadap peserta didik.

\section{Simpulan}

Implementasi Metode Diskusi pada pembelajaran PAI siswa kelas XI MIPA di SMA Negeri 2 Sijunjung tahun ajaran 2021/2022 dapat dilakukan beberapa tahap dalam melakukan proses pembelajaran yaitu adanya persiapan guru dalam untuk memulai pembelajaran, pada saat pelaksanaan pebelajaran dan akhir pembelajaran. Selanjutnya dalam mengunnakan suatu metode pasti ada faktor-faktor yang terjadi dalam pembelajaran. Faktor tersebut yaitu penghambat dan factor pendukung dalam pembelajaran. Semua faktor tersebut dapat diminimalisir dengan kreatifitas yang dimiliki guru dalam membuat diskusi menjadi lebih hidup dan menarik yang menggugah semangat belajar siswa terutama pada pembelajaran PAI.

\section{Referensi}

Arief, Armai (2002). Pengantar Ilmu dan Metodologi Pendidikan Islam. Jakarta: Penerbit Ciputat Pers

Azyumardi Azra.1999. Pendidikan Islam dan Modernisasi menuju menuju millennium Baru,Jakarta: Logos Wacana

Departemen Agama RI. 2009. Al-Qur'an dan Terjemahnya, Surabaya: CV Fajar Mulia.

Haris Herdiansyah. 2014. Metodologi Penelitian Kualitatif. Jakarta Selatan: Salemba Humanika. 
Nurhayati dan Sulaiman: Implementasi Metode Diskusi Pada Pembelajaran Pendidikan...

Maloeng, Lexy.J. (2013). Metodologi Penelitian Kualitatif. Bandung: PT Remaja Rosdakarya.

Muhaimin, Akhmad. 2011. Bimbingan dan konseling disekolah. Yogyakarta: Ar- Ruzz Media.

Muhibbin Syah 1995, Psikologi Pendidikan Suatu Pendekatan Yang Baru, Bandung: Remaja Rosdakarya.

Mulyasa. 2003. Kurikulum Berbasis Kompetensi, Konsep, dan Karasteristik, Implementasi, Bandung: Rosdakarya.

Mustaqim, dkk. 2010. Psikologi Pendidikan. Jakarta: Rineka Cipta.

Pupuh Faturrohman dan M. Sobry Sutikno. 2010. Strategi Belajar Mengajar, Bandung, PT.Refika Aditama.

Samrin, S.2015. Pendidikan Agama Islam Dalam Sistem Pendidikan Nasional di Indonesia.Jurnal Al-Ta'dib Vol. 8 No.1.

Syaifuddin, (2006) Design Pembelajaran dan Implementasinya, Ciputat: PT. Quantum Teaching.

Syaiful Bahri dan Aswan Zain. 2010. Strategi Belajar Mengajar. Jakarta: Rineka Cipta.

Slameto. 2013. Belajar dan Faktor-faktor yang mempengaruhi. Rineka Cipta: Jakarta.

ualitas Guru di Era Global, Erlangga Groub.

Republik Indonesia, Undang-Undang Nomor 20 Tahun 2003. 2011. tentang Sistem Pendidikan Nasional; Jakarta: Sinar Grafika. 